\title{
Interaction between Soybean Cultivars and Seed Density
}

\author{
Igor Oliveri Soares', Pedro Milanez de Rezende1, Adriano Teodoro Bruzi1*, \\ Alan Mario Zuffo' ${ }^{1}$ Everton Vinicius Zambiazzi' ${ }^{1}$, Vanoli Fronza ${ }^{2}$, Cícero Monti Teixeira ${ }^{3}$ \\ ${ }^{1}$ Department of Agriculture, Federal University of Lavras (UFLA), Lavras, Brazil \\ ${ }^{2}$ Brazilian Agricultural Research Corporation (Embrapa-Soja), Londrina, Brazil \\ ${ }^{3}$ Agricultural Research Company of Minas Gerais (Epamig), Uberaba, Brazil \\ Email: adrianobruzi@dag.ufla.br
}

Received 26 April 2015; accepted 14 June 2015; published 17 June 2015

Copyright (C) 2015 by authors and Scientific Research Publishing Inc.

This work is licensed under the Creative Commons Attribution International License (CC BY).

http://creativecommons.org/licenses/by/4.0/

c) (i) Open Access

\begin{abstract}
Plant, environmental conditions and management type will determine final crop yield. Enhanced yield can be reached by using well-adapted and potentially productive genotypes; all of them ally to crop cultural practices and management. Among these, seed density stands out, once it interferes with plant morphology and competition for water and nutrients. Thus, this study aimed to evaluate the effect of varied seed densities on agronomic traits in soybean, besides identifying cultivars with wide adaptability to different environments and seed densities. Six soybean cultivars were assessed under four seed densities $\left(100,200,300\right.$ and 400 thousand plants $\left.\cdot \mathbf{h a}^{-1}\right)$, in nine different environments from Minas Gerais State, Brazil. The experimental design was a completely randomized block design with three replications. The BRSMG 760SRR and BRSMG 820RR cultivars had the best average performance independent of the environments and seed densities. The seed density of $\mathbf{3 0 0}$ thousand plants per hectare showed to be as the most adequate for soybean cultivation on the evaluated environments. Furthermore, seed density interacted with the agronomic traits in soybean.
\end{abstract}

\section{Keywords}

Glycine max L. Merrill, Genotypes, Yield, Plant Population

\section{Introduction}

Crop yield is regulated by plant, environment and management interaction. High yields are reached when well-

\footnotetext{
${ }^{*}$ Corresponding author.
}

How to cite this paper: Soares, I.O., de Rezende, P.M., Bruzi, A.T., Zuffo, A.M., Zambiazzi, E.V., Fronza, V. and Teixeira, C.M. (2015) Interaction between Soybean Cultivars and Seed Density. American Journal of Plant Sciences, 6, 1425-1434. 
adapted and potentially productive genotypes are grown; all of them ally to cultural practices and management required by the crop [1].

Seed density stands out as the most important management tool, directly interfering with interspecific and intraspecific competition for soil resources, especially water and nutrients, besides bringing about morphological changes in plants [2]. Among these changes, plant height, branch length, number of branches and fruitful nodes are major yield components.

Lima [3] also pointed out that seed density setting is essential for proper plant growth, biomass accumulation and grain production, once it affects light, water and nutrient uses [4].

The researches carried by [5] strengthen the direct influence of genotype on plant response to seed density, i.e. some cultivars have enhanced yield in high populations, yet others perform better at low densities.

Results reported by [6] also corroborate cultivar-population interaction. The authors observed improved yields with a stand of 550 thousand plants $\cdot \mathrm{ha}^{-1}$, when assessing different soybean cultivars in three plant populations (250, 400 and 550 thousand plants $\cdot \mathrm{ha}^{-1}$ ).

Based on the above considerations, this study aimed to evaluate the effect of different seed densities on agronomic traits in soybean, in addition to identify cultivars with wide adaptability to the evaluated environments and seed densities.

\section{Material and Methods}

The experiments were performed in four distinct locations within Minas Gerais State, in Brazil, during the 2011-2012 season:

i) Experimental farm of the EPAMIG in Patos de Minas-MG, Brazil. It is located at 1074-m altitude and geographical coordinates $18^{\circ} 29^{\prime} 70^{\prime \prime} \mathrm{S}$ and $46^{\circ} 26^{\prime} 55^{\prime \prime} \mathrm{W}$.

ii) Experimental farm of the EPAMIG in Uberaba-MG, Brazil. It is located at 819-m altitude and geographical coordinates $19^{\circ} 39^{\prime} 14^{\prime \prime S}$ and $47^{\circ} 58^{\prime} 11^{\prime \prime} \mathrm{W}$.

iii) Experimental area of the Federal Institute of Education, Science and Technology-Southern Minas Gerais, in Muzambinho. It is located at 1048-m altitude, $21^{\circ} 22^{\prime} 33^{\prime \prime} S$ latitude and $46^{\circ} 31^{\prime} 32^{\prime \prime} \mathrm{W}$ longitude.

iv) Private farm in the city of Iraí de Minas, which is located at 1029-m altitude, 18 $59^{\circ} 23^{\prime \prime S}$ latitude and $47^{\circ} 28$ '33"W longitude.

Additionally, during the 2012-2013 season, besides Patos de Minas, Uberaba and Iraí de Minas, we assessed the following locations:

v) Private farm in the city of Sacramento, which is located at $19^{\circ} 40^{\prime} 39^{\prime \prime} \mathrm{S}, 47^{\circ} 35^{\prime} 32^{\prime \prime} \mathrm{W}$ and $1027-\mathrm{m}$ altitude.

vi) Experimental area of the Center of Scientific and Technological Development in Farming-Muquém, which belongs to the Federal University of Lavras (UFLA), in Lavras-MG, Brazil. The geographical coordinates are $21^{\circ} 12^{\prime} 11^{\prime \prime S}$ latitude and $44^{\circ} 58^{\prime} 47^{\prime \prime} \mathrm{W}$ longitude, and an altitude of $954 \mathrm{~m}$.

Soil was prepared following no-tillage system, with furrows spaced at $0.50 \mathrm{~m}$. Fertilization was performed in accordance with protocol developed by the Commission of Soil Fertility of the Minas Gerais State [7]. Before sowing, seeds were inoculated with Bradyrhizobium japonicum liquid inoculant at a ratio of 1,200,000 bacteria per seed. Six cultivars were used, three conventional and three transgenic (Table 1).

Experimental plots were composed of four $5.0 \mathrm{~m}$ rows spaced at $0.50 \mathrm{~m}$. The two central rows performed the useful area disregarded the last $0.5 \mathrm{~m}$ at both ends. The experimental design was a completely randomized block

\begin{tabular}{cccc}
\hline Table 1. Cultivars studied in interaction between soybean cultivars and seed density. & \\
\hline Cultivar & Glyphosate resistance & Maturity group & Growth habit \\
BRSMG 771 & No & 7.7 & Determinate \\
BRSMG 752S & No & 7.5 & Non-determinate \\
BRSMG 810C & No & 8.1 & Determinate \\
BRSMG 760SRR & Yes & 7.6 & Determinate \\
BRSMG 780RR & Yes & 7.8 & Determinate \\
BRSMG 820RR & Yes & 8.2 & \\
\hline
\end{tabular}


design with three replications in a factorial scheme. Four seed densities were assessed (100, 200, 300 and 400 thousand plants per hectare). Sowing was done manually and thinning made 15 days after germination, ensuring an intended plant stand. Weed control was performed by conventional method.

We evaluated the following traits: first pod insertion height- $\mathrm{IH}$ (distance between plant neck up to the first insertion node, in centimeters, taken randomly from 5 plants); plant total height- $\mathrm{TH}$ (from plant neck to the end of the main stem, in centimeters, taken randomly from 5 plants); lodging level, according to [8] with the following score: all plants are erect \#1, half stand is bent or slightly lodged \#2, all plants mildly bent or $25 \%$ 50\% lodged \#3, for all plants strictly bent 50\% - 80\% lodged \#4 and for more than 80\% lodged plants \#5; 100 grain mass in grams- GM; aside from yield $-\mathrm{Y}$ in $\mathrm{kg} \cdot \mathrm{ha}^{-1}$ after correction of seed weights to $13 \%$ moisture.

Individual analyses for all traits per season and environment were performed using the statistical model as in Equation (1):

$$
Y_{i j k}=\mu+\alpha_{\mathrm{i}}+b_{k}+\beta_{j}+\alpha \beta_{i j}+e_{i j k}
$$

In which:

$Y_{i j k}$ : observed value in the plot, which had $i$ density in $k$ block and with $j$ cultivar;

$\mu$ : constant inherent of all observation;

$\alpha_{i}: i$ density effect;

$b_{k}: k$ block effect;

$\beta_{j}: j$ cultivar effect;

$\alpha \beta_{i j}$ : cultivar $\times$ density interaction effect;

$e_{i j k}$ : experimental error.

Joint analysis of all environments followed the statistical model presented in Equation (2):

$$
Y_{i j k l}=m+c_{i}+b_{(j) l}+d_{k}+(c d)_{i k}+a_{l}+(c a)_{i l}+(d a)_{k l}+(c d a)_{i k l}+e_{i j k(l)}
$$

In which:

$Y_{i j k l}$ : observed value in the plot, which had idensity in $j$ block with $k$ cultivar in environment $l$.

$m$ : general average;

$c_{i}: i$ density effect;

$b_{j(1)}: j$ block effect within environment 1 ;

$d_{k}: k$ cultivar effect;

$(c d)_{i k}$ : cultivar and density interaction effect;

$a_{l}$ : effect of the environment $\mathrm{l}$;

$(\mathrm{ca})_{i l}$ : cultivar and environment interaction effect;

$(d a)_{k l}$ : density and environment interaction effect;

$(c d a)_{i k l}$ : effect of the interaction among cultivar, density and environment;

$e_{i j k(l)}$ : experimental error.

Data were subjected to statistical analysis with the aid of Sisvar ${ }^{\circledR}$ software [9], using Scott-Knott test [10] at $5 \%$ probability for means' comparison and regression analysis for quantitative traits [11]. Precision was measured by estimating variation coefficients and accuracy.

Variation coefficient was calculated through the following model (Equation (3)):

$$
C V=\frac{\sqrt{R M S}}{\mu} \times 100
$$

In which:

$R M S$ : residual mean square;

$\mu$ : general average.

Yet accuracy was calculated using the model presented below (Equation (4)):

$$
r=\sqrt[2]{1-\frac{1}{F_{c}}} \times 100
$$

In which:

$r$ : accuracy expressed in percentage;

$F_{c}: F$ calculated value. 


\section{Results}

The joint variance analysis (Table 2) shows a difference in density factor for yield, plant total height and first pod insertion. However, in cultivar and environment variation sources, there was significant difference for all traits.

The interaction $\mathrm{C} \times \mathrm{D}$ had no significance for yield, 100-grain mass and plant total height. On the other hand, the interaction $\mathrm{C} \times \mathrm{A}$ was significant for all traits. Moreover, $\mathrm{D} \times \mathrm{A}$ interaction had no significant results for 100-grain mass. Accuracy ranged from 97.30 to 99.67. Yet for variation coefficient (VC), estimates between 34.75\% and 5.80\% were observed (Table 2).

Mean yield values presented a wide variation for cultivars with the lowest value obtained by BRSMG 752S cultivar (2882 $\left.\mathrm{kg} \cdot \mathrm{ha}^{-1}\right)$. However, the highest estimate for BRSMG 760SRR one (3507 $\mathrm{kg} \cdot \mathrm{ha}^{-1}$ ) as seen in (Table 3). The GM trait varied on an average of $14.9 \mathrm{~g}$ for BRSMG 780RR and, $17.8 \mathrm{~g}$ for BRSMG 771 (Table 3).

Regarding plant total height, all studied cultivars reached height suitable for mechanized harvesting, which ranged from $77.2 \mathrm{~cm}$ (BRSMG 810C) to $93.2 \mathrm{~cm}$ (BRSMG 780RR) (Table 3). Among the cultivars, IH fluctuated from $14.4 \mathrm{~cm}$ (BRSMG 752S) to $18.7 \mathrm{~cm}$ (BRSMG 780RR) (Table 3). Lastly, lodging levels differed between 1.3 (BRSMG 752S) and 2.0 (BRSMG 810C) (Table 3).

Grain yield was markedly different among the assessed environments. From which, Sacramento (12/13) highlighted with an average yield of $3617 \mathrm{~kg} \cdot \mathrm{ha}^{-1}$. Contrarily, Patos de Minas (12/13) had the smallest yield of $2645 \mathrm{~kg} \cdot \mathrm{ha}^{-1}$ (Table 4). Concerning GM, we observed a mean variation from 14.0 to $19.1 \mathrm{~g}$ between Iraí de Minas (11/12) and Muzambinho (11/12), respectively (Table 4).

Table 2. Summary of the joint variance analysis for yield in $\mathrm{kg} \cdot \mathrm{ha}^{-1}(\mathrm{Y}), 100$-grain mass in $\mathrm{g}(\mathrm{GM})$, plant total height (TH), first pod insertion height in cm (IH) and lodging level (LL).

\begin{tabular}{|c|c|c|c|c|c|c|}
\hline \multirow{2}{*}{ VF } & \multicolumn{6}{|c|}{ MS } \\
\hline & DF & $\mathrm{Y}$ & GM & $\mathrm{TH}$ & $\mathrm{IH}$ & LL \\
\hline Densities (D) & 3 & $20899151.16^{*}$ & 2.81 & $4703.83^{*}$ & $598.37^{*}$ & 1.37 \\
\hline Replications (R) & 18 & 246057.50 & 1.67 & 109.07 & 27.55 & 0.57 \\
\hline Cultivars (C) & 5 & $7406862.64^{*}$ & $131.87^{*}$ & $4062.52^{*}$ & $200.36^{*}$ & $7.89^{*}$ \\
\hline $\mathrm{D} \times \mathrm{C}$ & 15 & 164934.24 & 1.12 & 91.28 & $19.01^{*}$ & $0.88^{*}$ \\
\hline Environments (E) & 8 & $7482804.98^{*}$ & $189.25^{*}$ & $6178.44^{*}$ & $630.90^{*}$ & $20.46^{*}$ \\
\hline $\mathrm{C} \times \mathrm{E}$ & 40 & $3763946.24^{*}$ & $22.74^{*}$ & $488.96^{*}$ & $67.24^{*}$ & $2.67^{*}$ \\
\hline $\mathrm{D} \times \mathrm{E}$ & 24 & $751557.24^{*}$ & 1.08 & $135.18^{*}$ & $22.04^{*}$ & $0.76^{*}$ \\
\hline $\mathrm{C} \times \mathrm{D} \times \mathrm{E}$ & 120 & $217508.12^{*}$ & 0.91 & $56.28^{*}$ & 11.89 & $0.46^{*}$ \\
\hline Error & 414 & 96904.05 & 0.88 & 56.03 & 10.67 & 0.31 \\
\hline Fc (Cultivars) & 647 & 74.79 & 150.58 & 72.50 & 18.79 & 25.49 \\
\hline Accuracy & & 99.33 & 99.67 & 99.30 & 97.30 & 98.01 \\
\hline VC (\%) & & 10.01 & 5.80 & 8.78 & 19.10 & 34.75 \\
\hline General mean & & 3142.76 & 16.14 & 85.29 & 17.09 & 1.60 \\
\hline
\end{tabular}

"Significant at 95\% confidence level by F-test.

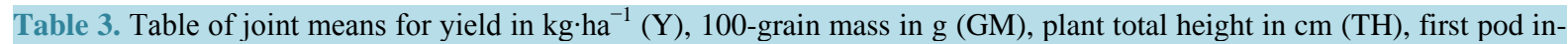
sertion height in $\mathrm{cm}(\mathrm{IH})$ and lodging level (LL) of the studied cultivars.

\begin{tabular}{|c|c|c|c|c|c|}
\hline Cultivars & $\mathrm{Y}$ & GM & $\mathrm{TH}$ & $\mathrm{IH}$ & LL \\
\hline BRSMG 760SRR & $3507 a$ & $15.3 c$ & $89.1 \mathrm{~b}$ & $17.1 \mathrm{c}$ & $1.4 \mathrm{a}$ \\
\hline BRSMG 820RR & $3440 a$ & $15.9 c$ & $88.4 \mathrm{~b}$ & $17.9 \mathrm{~b}$ & $1.6 b$ \\
\hline BRSMG 810C & $3025 b$ & $17.1 \mathrm{~b}$ & $77.2 \mathrm{~d}$ & $16.9 \mathrm{c}$ & $2.0 \mathrm{c}$ \\
\hline BRSMG 780RR & $3007 b$ & $14.9 \mathrm{~d}$ & $93.2 \mathrm{a}$ & $18.7 \mathrm{a}$ & $1.9 \mathrm{c}$ \\
\hline BRSMG 771 & 2997b & $17.8 \mathrm{a}$ & 79.3d & $17.3 \mathrm{c}$ & $1.5 b$ \\
\hline BRSMG 752S & 2882c & $15.8 \mathrm{c}$ & $84.6 \mathrm{c}$ & $14.4 d$ & 1.3a \\
\hline
\end{tabular}

Means followed by the same letter belong to the same group according to Scott-Knott test at 95\% confidence level. 


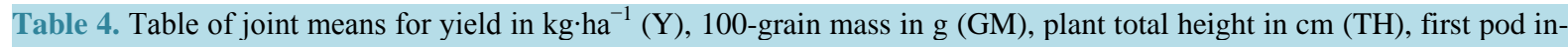
sertion height in $\mathrm{cm}(\mathrm{IH})$ and lodging level (LL) of the studied environments.

\begin{tabular}{|c|c|c|c|c|c|}
\hline Environments & $\mathrm{Y}$ & GM & $\mathrm{TH}$ & $\mathrm{IH}$ & LL \\
\hline Sacramento $12 / 13$ & $3617 a$ & $17.6 \mathrm{~b}$ & $96.8 \mathrm{a}$ & 17.3c & $2.4 \mathrm{e}$ \\
\hline Muzambinho 11/12 & $3508 b$ & 19.1a & $87.9 \mathrm{c}$ & $19.0 \mathrm{~b}$ & $2.4 \mathrm{e}$ \\
\hline Lavras 12/13 & $3384 c$ & $17.3 \mathrm{~b}$ & $84.1 \mathrm{~d}$ & $17.8 \mathrm{c}$ & $1.4 \mathrm{~b}$ \\
\hline Uberaba 11/12 & 3163d & $14.3 \mathrm{f}$ & $86.5 \mathrm{c}$ & $16.2 \mathrm{~d}$ & $1.1 \mathrm{a}$ \\
\hline Iraí de Minas 11/12 & 3136d & $14.0 \mathrm{f}$ & 78.0e & $12.9 \mathrm{e}$ & $1.3 \mathrm{~b}$ \\
\hline Uberaba 12/13 & $3118 d$ & 15.1e & $92.1 \mathrm{~b}$ & $17.8 \mathrm{c}$ & $1.5 \mathrm{c}$ \\
\hline Iraí de Minas 12/13 & $2858 \mathrm{e}$ & $16.2 \mathrm{c}$ & $95.4 \mathrm{a}$ & $19.2 \mathrm{~b}$ & $1.8 \mathrm{~d}$ \\
\hline Patos de Minas 12/13 & $2852 \mathrm{e}$ & $15.8 \mathrm{~d}$ & $68.1 \mathrm{f}$ & 12.1e & $1.1 \mathrm{a}$ \\
\hline Patos de Minas 11/12 & $2645 f$ & $15.9 \mathrm{~d}$ & $78.4 \mathrm{e}$ & $21.5 \mathrm{a}$ & $1.3 \mathrm{~b}$ \\
\hline
\end{tabular}

Means followed by the same letter belong to the same group according to Scott-Knott test at 95\% confidence level.

There were differences on plant TH. The highest plants were found in Sacramento (12/13) and Iraí de Minas (12/13), where they were estimated to have on average 96.8 and $95.4 \mathrm{~cm}$, respectively. With regard to IH, a variation from 12.1 to $21.5 \mathrm{~cm}$ was observed for plants from Patos de Minas between 12/13 and 11/12 respectively (Table 4). Yet for LL, levels of 1.1 in Patos de Minas (12/13) and Uberaba (11/12) up to 2.4 in Sacramento (12/13) and Muzambinho (11/12) (Table 4).

A quadratic effect was observed for the interaction $\mathrm{C} \times \mathrm{D}$ on grain yield, with increase in yield for population densities up to 337 thousand plants $\cdot \mathrm{ha}^{-1}$, then it starts to decline (Figure 1(a)).

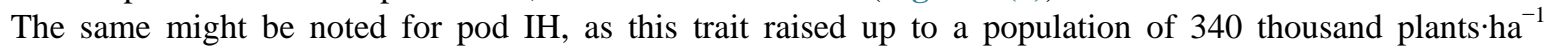
(Figure 1(b)). For plant TH, there is a quadratic effect in compliance with plant density increase (Figure 1(c)). A model goodness of fit was checked for the three cases, and estimates with $\mathrm{R}^{2}$ above $99 \%$.

Studying the interaction between cultivars and seed densities, it is noteworthy to mention that regarding plant lodging, cultivar behavior is assorted by plant densities. BSRMG 780RR and BRSMG 820RR presented a constant lodging regardless of plant density. Conversely, BRSMG 810C had a LL growing behavior (Figure 2(a)).

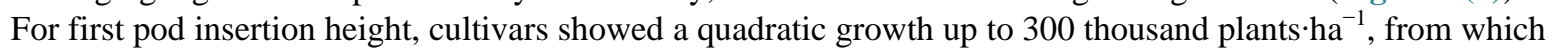
estimates started to reduce (Figure 2(b)).

As observed for the $\mathrm{C} \times \mathrm{D}$ interaction, lodging behavior did not coincide among the cultivars when studying the interaction environment and plant population (Figure 3(a)).

In the same light of $\mathrm{C} \times \mathrm{D}$ interaction, $\mathrm{TH}$ and $\mathrm{IH}$ had same behavior. Environments presented a quadratic growth up to reach 300 thousand plants $\cdot \mathrm{ha}^{-1}$, from which values reduced (Figure 3(b) and Figure 3(c)).

As seen in Figure 1(a), yield had also a quadratic behavior in all environments when assessing the interaction $\mathrm{E} \times \mathrm{D}$. Moreover, there is an increase in yield until the population of 300 thousand plants $\mathrm{ha}^{-1}$ with further decline (Figure 3(d)).

As observed for the $\mathrm{C} \times \mathrm{D}$ interaction, lodging behavior did not coincide among the cultivars when studying the interaction environment and plant population (Figure 3(a)).

In the same light of $\mathrm{C} \times \mathrm{D}$ interaction, $\mathrm{TH}$ and $\mathrm{IH}$ had same behavior. Environments presented a quadratic growth up to reach 300 thousand plants $\cdot \mathrm{ha}^{-1}$, from which values reduced (Figure 3(b) and Figure 3(c)).

As seen in Figure 1(a), yield had also a quadratic behavior in all environments when assessing the interaction

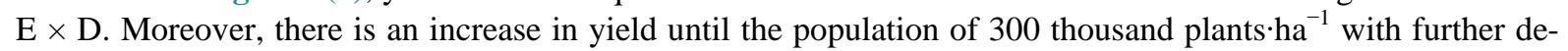
cline (Figure $3(\mathrm{~d})$ ).

For the $\mathrm{E} \times \mathrm{C}$ interaction, it was possible to identify which cultivar has presented the best performance at each environment. This way, it was observed that BRSMG 820RR achieved the best results in Iraí de Minas, during both seasons (Table 5). In addition to this cultivar, BRSMG 760SRR, BRSMG 810C and BRSMG771 have also shown superior efficiency in Lavras (12/13) (Table 5). In Uberaba, BRSMG 820RR and BRSMG 760SRR achieved the greatest yields; while in 12/13, BRSMG 760SRR and BRSMG 752S did (Table 5). 


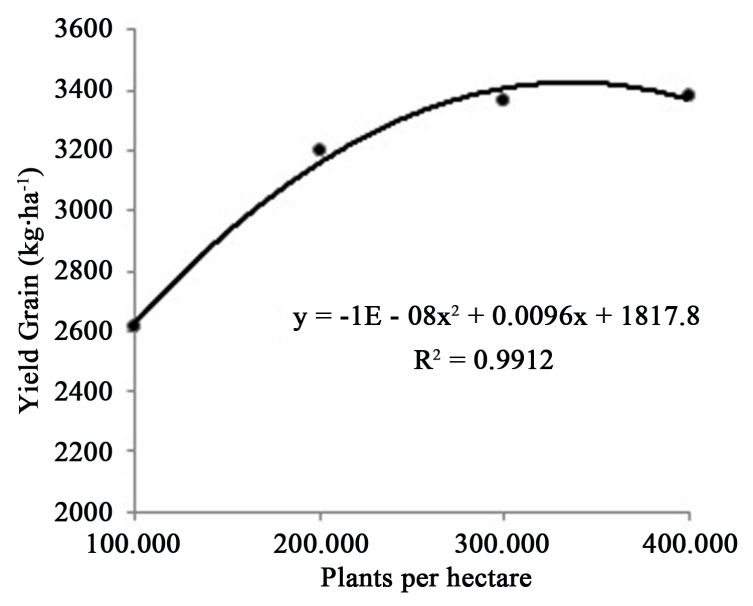

(a)

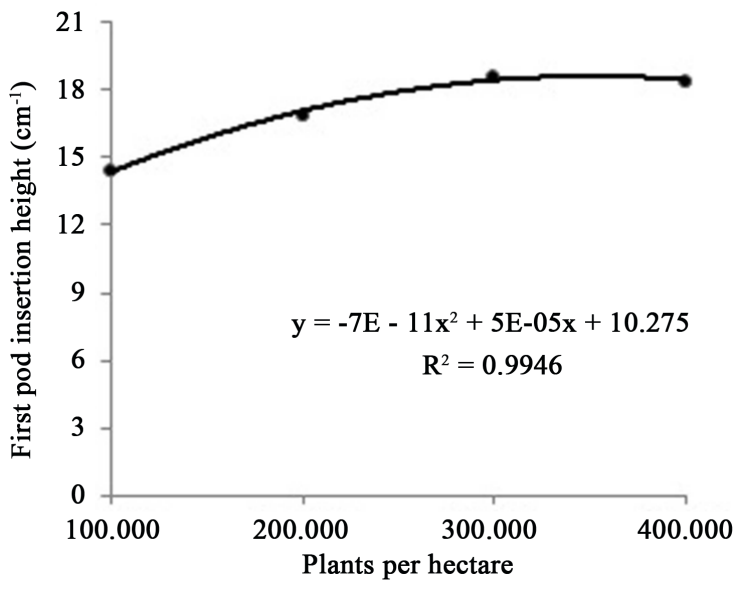

(b)

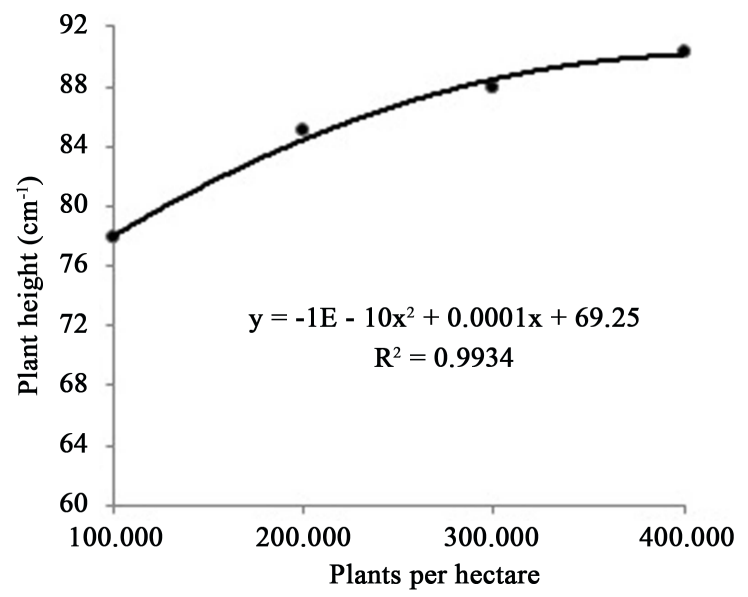

(c)

Figure 1. Regression curve for cultivars' mean yield (a); first insertion height (b) and plant total height (c); according to plant density.

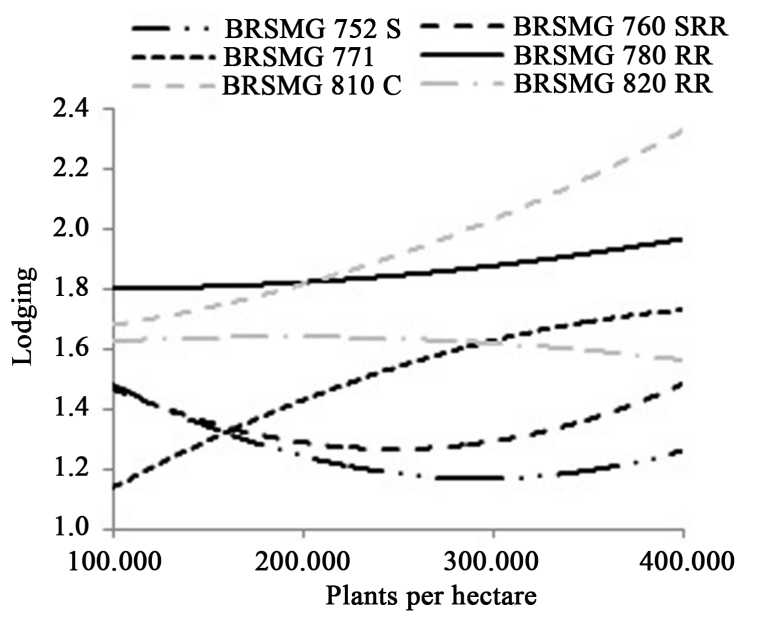

(a)

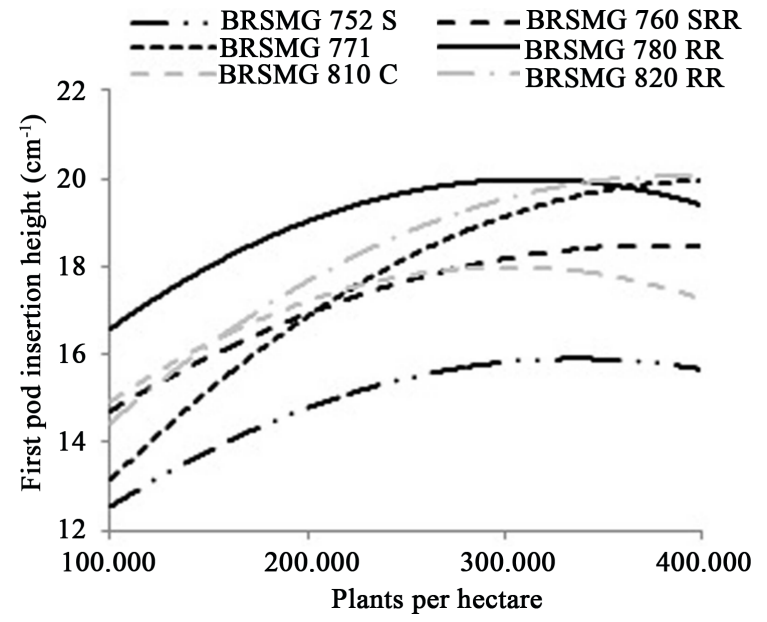

(b)

Figure 2. Regression curve for lodging (a) and first insertion height (b), according to the interaction between cultivars $\times$ densities. 


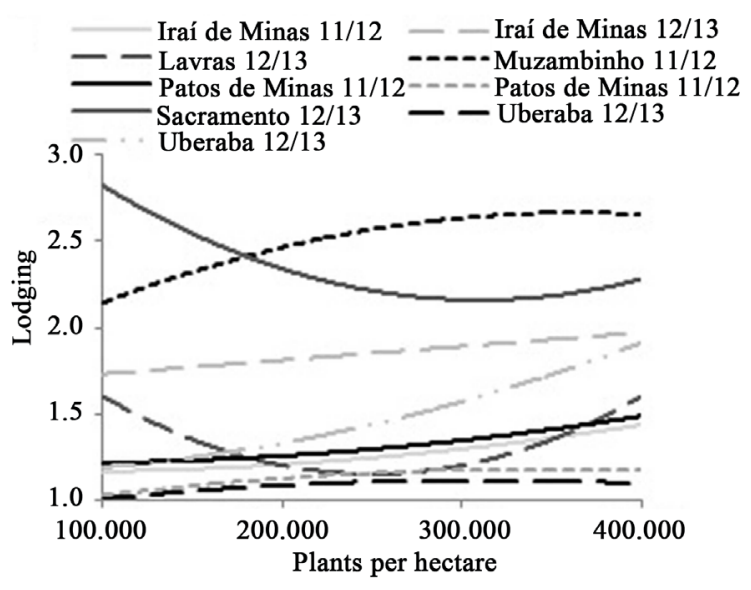

(a)

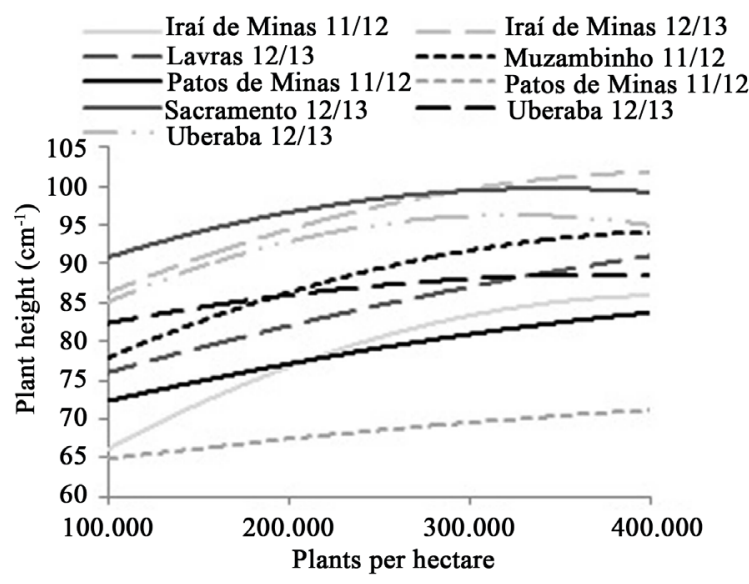

(c)

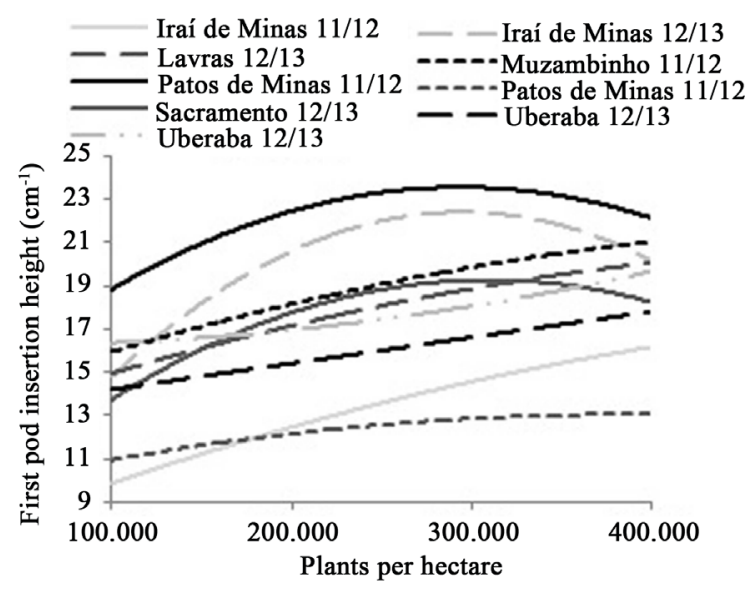

(b)

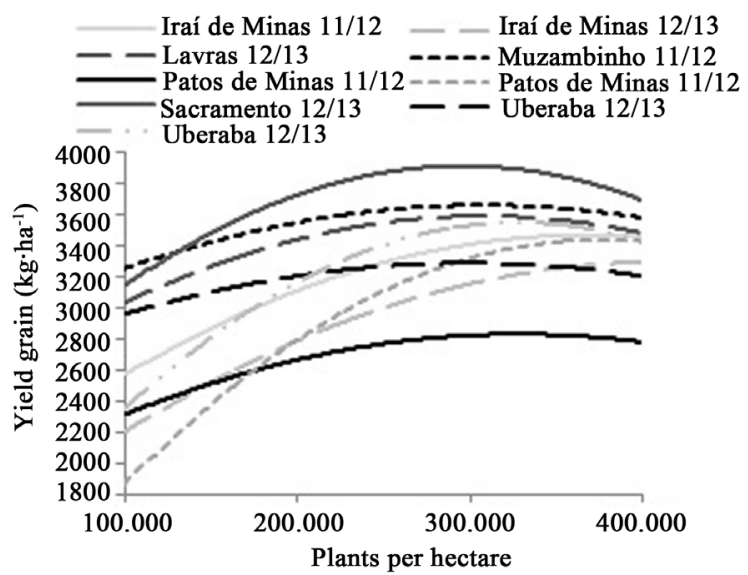

(d)

Figure 3. Regression curve for lodging (a); first insertion height (b); plant total height (c) and yield grain (d); according to the interaction between environments $\times$ densities.

Table 5. Table of joint means for yield in $\mathrm{kg} \cdot \mathrm{ha}^{-1}(\mathrm{Y})$ in the interaction between environments $\times$ cultivars.

\begin{tabular}{cccccccccc}
\hline \multirow{2}{*}{ Cultivars } & \multicolumn{10}{c}{ Environments } \\
\cline { 2 - 10 } & $\begin{array}{c}\text { Iraí de } \\
\text { Minas 11/12 }\end{array}$ & $\begin{array}{c}\text { Iraí de } \\
\text { Minas 12/13 }\end{array}$ & $\begin{array}{c}\text { Lavras } \\
12 / 13\end{array}$ & $\begin{array}{c}\text { Muzambinho } \\
11 / 12\end{array}$ & $\begin{array}{c}\text { Patos de } \\
\text { Minas } 11 / 12\end{array}$ & $\begin{array}{c}\text { Patos de } \\
\text { Minas } 12 / 13\end{array}$ & $\begin{array}{c}\text { Sacramento } \\
12 / 13\end{array}$ & $\begin{array}{c}\text { Uberaba } \\
11 / 12\end{array}$ & $\begin{array}{c}\text { Uberaba } \\
12 / 13\end{array}$ \\
\hline BRSMG 820RR & $3997 \mathrm{aA}$ & $3574 \mathrm{aC}$ & $3507 \mathrm{aC}$ & $3741 \mathrm{aB}$ & $3284 \mathrm{bD}$ & $3121 \mathrm{aD}$ & $3532 \mathrm{dC}$ & $353 \mathrm{aC}$ & $2668 \mathrm{cE}$ \\
BRSMG 760SRR & $3594 \mathrm{bC}$ & $2426 \mathrm{cE}$ & $3471 \mathrm{aD}$ & $3868 \mathrm{aB}$ & $4396 \mathrm{aA}$ & $3290 \mathrm{aD}$ & $3459 \mathrm{dD}$ & $3613 \mathrm{aC}$ & $3440 \mathrm{aD}$ \\
BRSMG 780RR & $3392 \mathrm{bA}$ & $3011 \mathrm{bB}$ & $2912 \mathrm{bB}$ & $2728 \mathrm{~dB}$ & $3513 \mathrm{bA}$ & $2751 \mathrm{bB}$ & $2799 \mathrm{eB}$ & $2886 \mathrm{cB}$ & $3065 \mathrm{bB}$ \\
BRSMG 810C & $2878 \mathrm{cC}$ & $3017 \mathrm{bC}$ & $3589 \mathrm{aA}$ & $3260 \mathrm{cB}$ & $1620 \mathrm{cD}$ & $2755 \mathrm{bC}$ & $3777 \mathrm{cA}$ & $3322 \mathrm{bB}$ & $2999 \mathrm{bC}$ \\
BRSMG 771 & $2587 \mathrm{dD}$ & $2608 \mathrm{cD}$ & $3775 \mathrm{aA}$ & $3470 \mathrm{bB}$ & $1337 \mathrm{dE}$ & $2936 \mathrm{bC}$ & $3886 \mathrm{bA}$ & $3215 \mathrm{bC}$ & $3150 \mathrm{bC}$ \\
BRSMG 752S & $2365 \mathrm{dE}$ & $2514 \mathrm{cE}$ & $3051 \mathrm{bD}$ & $3981 \mathrm{aB}$ & $1718 \mathrm{cF}$ & $2260 \mathrm{cE}$ & $4249 \mathrm{aA}$ & $2408 \mathrm{dE}$ & $3383 \mathrm{aC}$
\end{tabular}

Means followed by the same letter belong to the same group according to Scott-Knott test at 95\% confidence level.

BRSMG 760S RR had superior results in Patos de Minas (11/12), when compared to the others. Meanwhile, in Sacramento (12/13), BRSMG 752S got the best results (Table 4). Concerning seasons, BRSMG 760SRR and BRSMG 820RR can be detached for their outcomes during 12/13 (Table 5). In Uberaba, BRSMG 820RR and BRSMG 760SRR achieved the greatest yields; while in 12/13, BRSMG 760SRR and BRSMG 752S did (Table 5). 


\section{Discussion}

Good experimental accuracy is crucial for a successful field trial. We used two tools to measure this attribute. Variation coefficient can be classified according to [12], into low, when inferior to 10\%; medium, from 10 to $20 \%$; high, if it is between $20 \%$ and $30 \%$; and very high, for values superior to $30 \%$.

In this study, lodging was the trait that has obtained the major estimate. One possible explanation for such low precision is because of mean magnitude is inversely related in the estimation of the variation coefficient, i.e. for lower means, higher coefficients are expected. On the other side, when evaluating experimental precision by estimating accuracy, such effect is suppressed, becoming apparent that all traits have obtained a high estimate on this parameter, which leads to data interference.

Seed density influenced not only 100-grain weight but also lodging. This fact was unexpected as there is a direct relationship between plant population and lodging, i.e., increased densities are supposed to enhance lodging [13]. This result can be explained by the low variation of the lodging trait at the different assessed environments. However, regarding 100-grain mass, there is no report in the literature associating it with seed density, so corroborating with the current results.

As already mentioned, the various cultivars had influence on all characters. Although cultivars belong to the same breeding program, there are differences in their genetic background, cycle and other attributes; thus, evidencing the variability in this study. Other studies also report the same [14]-[16]. Such fact was also essential to ensure the significance of $\mathrm{C} \times \mathrm{E}$ and $\mathrm{C} \times \mathrm{D}$ interactions.

About environments, it must be mentioned that the study was carried at six different cities and two growing seasons. Therefore, there are fluctuations inherent to local variations as differences between the growing seasons. Local environmental factors likely represent a foreseeable variance such as soil fertility. However, the occurrence of rains, and even the incidence of high temperatures associated with seasonal fluctuations represent unpredictable variations, i.e. which occur fortuitously and cannot be controlled.

These environmental effects were essential for the significance of $\mathrm{C} \times \mathrm{E}$ interaction. Thus, these results reinforce the need to evaluate experiments at different conditions, i.e. considering distinct areas and seasons [17]. Mean yield from each environment proves these comments. There was a variation of $26.87 \%$ between the highest and the lowest estimate of yield for the most contrasting environments.

The interaction $\mathrm{C} \times \mathrm{E}$ indicated a lack of coincidences in performance among cultivars at the environments. Based on this interaction, it is possible to identify the most suitable cultivar for each environment, or even check which genotype gives an improved response. Cultivars BRSMG 760SRR and BRSMG 820RR showed large plasticity, since they had the best performance irrespectively of environment. Additionally, it must be reported that despite great yield, BRSMG 760SRR present a good earliness whether compared to the others; thereby being capable of a second harvest.

Among productivity components, GM has to be highlighted because the more the weight gain, the greater the crop yield. According to the literature, 100 grains weigh about 16 g. Similar values were reported by [18]. We found an average value of $16.14 \mathrm{~g}$, corroborating with literature.

Plant height is directly related to crop yield, lodging level and efficiency of mechanized harvesting; thus, being an important trait. Furthermore, it is important to highlight that this parameter undergoes through environmental changes. The plant height between 60 and $120 \mathrm{~cm}$ are considered ideal [19]. Therefore, our findings reach the ideal range, once the average height found in the current experiments were $85.29 \mathrm{~cm}$, which is within the previously mentioned.

As well as plant height, first pod insertion height influences mechanical harvesting. If $\mathrm{IH}$ is below $10 \mathrm{~cm}$, losses may occur during operation, since harvester operates near the ground. As stated by [20], the ideal IH is about $15 \mathrm{~cm}$. Here, we observed an average height of $17.09 \mathrm{~cm}$.

Since it is most affected by TH, lodging level plays an important role in cultivar selection, once lodged plants impair mechanized harvesting. Our assessments had an average score of 1.60 for LL. This value is considered fully operational to mechanized harvesting and does not result in any loss [8].

Regression results, for all traits except lodging, denote a quadratic growth up to densities of 300 thousand plants $\cdot \mathrm{ha}^{-1}$, with subsequent reduction. Thus, it is clear that the best plant population to be used in all environments and for all cultivars is 300 thousand plants $\mathrm{ha}^{-1}$. At lower densities, branching is more intense; however, small stands were not worth yields. On the other hand, a population of 400 thousand plants $\cdot \mathrm{ha}^{-1}$, for the large number of plants per area, led to an increased competition, damaging plant architecture. 
This way, it can be inferred the 300 thousand plants $\cdot \mathrm{ha}^{-1}$ as the most adequate, promoting well-structured plants and a great vegetative growth, besides enhanced yields.

\section{Conclusion}

We concluded that there is an interaction between seed densities with soybean cultivars and agronomic traits. The population of 300 thousand plants per hectare, which shows up as the most suitable for soybean cultivation at all evaluated environments, can be highlighted. Yet for the cultivars, BRSMG 760SRR and BRSMG 820RR have improved performance, independent of the environment and seed density.

\section{Acknowledgements}

The authors express their thanks to the CNPq (Conselho Nacional de Desenvolvimento Científico e Tecnológico), Capes (Coordenação de aperfeiçoamento de pessoal de nível superior), FAPEMIG (Fundação de amparo à pesquisa do Estado de Minas Gerais) for granting a doctoral and masters scholarship. To EMPRAPA/SOJA (Empresa Brasileira de Pesquisa Agropecuária) and UFLA (Universidade Federal de Lavras) and FAPEMIG (Fundação de amparo à pesquisa do Estado de Minas Gerais) for the financial and logistic support.

\section{References}

[1] Mauad, M., Silva, T.L.B., Neto, A.I.A. and Abreu, V.G. (2010) Influência da densidade de semeadura sobre características agronômicas na cultura da soja. Agrarian, 3, 175-181.

[2] Argenta, G., Silva, P.R.F. and Sangol, L. (2001) Arranjo de plantas em milho: análise do estado da-arte. Ciência Rural, 31, 1075-1084. http://dx.doi.org/10.1590/S0103-84782001000600027

[3] Lima, S.F., Alvarez, R.C.F., Theodoro, G.F., Bavaresco, M. and Silva, K.S. (2012) Efeito da semeadura em linhas cruzadas sobre a produtividade de grãos e a severidade da ferrugem asiática da soja. Bioscience Journal, 28, 954-962.

[4] Procópio, S.O., Balbinot Junior, A.A., Debiase, H., Franchini, J.C. and Panison, F. (2013) Plantio cruzado na cultura da soja utilizando uma cultivar de hábito de crescimento indeterminado. Revista Ciência Agrárias, 56, 319-325. http://dx.doi.org/10.4322/rca.2013.048

[5] Dutra, L.M.C., Ludwig, M.P., Lucca Filho, O.A., Zabot, L., Lisboa, J.I. and Uhry, D. (2007) População de plantas em soja. In: Reunião De Pesquisa De Soja Da Região Sul, Universidade Federal de Santa Maria, Santa Maria, 95.

[6] Ludwig, M.P., Dutra, L.M.C., Lucca Filho, O.A., Zabot, L., Jauer, A. and Uhry, D. (2011) Populações de plantas na cultura da soja em cultivares convencionais e Roundup Ready ${ }^{\mathrm{TM}}$. Revista Ceres, 58, 305-313. http://dx.doi.org/10.1590/S0034-737X2011000300010

[7] Comissão de Fertilidade do Solo do Estado de Minas Gerais (1999) Recomendações para o uso de corretivos e fertilizantes em Minas Gerais. 5a Aproximação, MG, Viçosa.

[8] Bernard, R.L., Chamberlain, D.W. and Lawrece, R.D. (1965) Results of the cooperative Uniform Soybean Tests. USDA, Washington DC.

[9] Ferreira, D.F. (2000) Sistema de análises de variância para dados balanceados. UFLA, Lavras (SISVAR 4.1 pacote computacional).

[10] Scott, A.J. and Knott, M.A. (1974) A Cluster Analysis Method for Grouping Means in the Analysis of Variance. Biometrics, 30, 507-512. http://dx.doi.org/10.2307/2529204

[11] Ferreira, D.F. (2011) Sisvar: A Computer Statistical Analysis System. Ciência e Agrotecnologia, 35, 1039-1042.

[12] Pimentel-Gomes, F. (2009) Curso de estatística experimental. 15th Edition, FEALQ, Piracicaba.

[13] Tourino, M.C.C., Rezende, P.M.D. and Salvador, N. (2002) Espaçamento, densidade e uniformidade de semeadura na produtividade e características agronômicas da soja. Pesquisa Agropecuária Brasileira, 37, 1071-1077. http://dx.doi.org/10.1590/s0100-204x2002000800004

[14] Fleck, N.G., Lamego, F.P., Schaedler, C.E. and Ferreira, F.B. (2007) Resposta de cultivares de soja à competição com cultivar simuladora da infestação de plantas concorrentes. Scientia Agraria, 8, 213-218. http://dx.doi.org/10.5380/rsa.v8i3.9520

[15] Rezende, P.M.D. and Carvalho, E.A. (2007) Avaliação de cultivares de soja [Glycine max (L.) Merrill] para o Sul de Minas Gerais. Ciência e Agrotecnologia, 31, 1616-1623. http://dx.doi.org/10.1590/s1413-70542007000600003

[16] Pires, L.P.M., Peluzio, J.M., Cancellier, L.L., Santos, G.R.R., Colombo, G.A. and Afférri, F.S. (2012) Performance of Soybean Genotypes in Central-South Region on Tocantins State, Crop Season 2009/2010. Bioscience Journal, 28, 214223. 
[17] Silveira Neto, A.D., Oliveira, E.D., Oliveira, A.B.D., Godoi, C.D., Prado, C.D.O. and Pinheiro, J.B. (2005) Desempenho de Linhagens de Soja em Diferentes Locais e Épocas de Semeadura em Goiás. Pesquisa Agropecuária Tropical, 35, 103-108.

[18] Avila, W., Perin, A., Guareschi, R.F. and Gazolla, P.R. (2008) Influência do tamanho da semente na produtividade de variedades de soja. Agrarian, 1, 89-95.

[19] Carvalho, E.R., Rezende, P.M.D., Ogoshi, F.G.A., Botrel, É.P., Alcantara, H.P. and Santos, J.P. (2010) Desempenho de cultivares de soja [Glycine max (L) Merrill] em cultivo de verão no Sul de Minas Gerais. Ciência e Agrotecnologia, 34, 892-899. http://dx.doi.org/10.1590/s1413-70542010000400014

[20] Marcos Filho, J. (1986) Produção de sementes de soja. Fundação Cargill, Campinas. 